\title{
Students' Academic Resilience Profiles based on Gender and Cohort
}

\author{
(Profil Resiliensi Akademik Mahasiswa berdasarkan Jenis Kelamin dan Tahun Angkatan)
}

\author{
Suciani Latif ${ }^{1 *}$, Muhammad Amirullah ${ }^{2}$ \\ ${ }^{1}$ Department of Guidance and Counseling, Faculty of Education, Universitas Negeri Makassar, \\ Tamalate St. No. 1, Makassar, South Sulawesi, 90222 Indonesia \\ ${ }^{2}$ Department of Guidance and Counseling, Sekolah Tinggi Keguruan dan Ilmu Pendidikan Muhammadiyah Barru, \\ K.H. Ahmad Dahlan St. No. 2, Barru, South Sulawesi, 90761 Indonesia \\ *corresponding author, e-mail: suciani.latif@unm.ac.id
}

Article received: April $25^{\text {th }} 2020$; revised: September $14^{\text {th }} 2020$; accepted: September $19^{\text {th }} 2020$

\begin{abstract}
This study examined the differences in the students' academic resilience based on gender and cohort. Participants were students of Department of Educational Psychology and Guidance, Faculty of Education, Universitas Negeri Makassar in the academic years of 2013, 2014, and 2015. They were comprised of 103 students, 77 females and 26 males. The instrument in this study was Academic Resilience Scale (ARS) adopted and modified from Martin and Marsh. Data were analyzed through Mann-Whitney statistical of non-parametric tests in order to measure the academic resilience level of gender difference and Kruskal Wallis to measure academic resilience of cohort difference. Results revealed that there was no difference in academic resilience between female and male students. It was also found that there is a significant difference in academic resilience among the students in the academic years of 2013, 2014 and 2015. Discussion, limitation, and recommendation were also provided in this study.
\end{abstract}

Keywords: resilience; academic year; female; male; university students

\begin{abstract}
Abstrak: Penelitian ini bertujuan untuk mengetahui tingkat resiliensi akademik mahasiswa berdasarkan jenis kelamin dan tahun angkatan. Partisipan merupakan mahasiswa angkatan 2013, 2014 dan 2015 Jurusan Psikologi Pendidikan dan Bimbingan Fakultas Ilmu Pendidikan Universitas Negeri Makassar. Jumlah partisipan sebanyak 103 mahasiswa yang terdiri dari 77 perempuan dan 26 laki-laki. Instrumen yang digunakan adalah Skala Resiliensi Akademik yang diadopsi dan dimodifikasi dari ARS yang dikembangkan oleh Martin \& Marsh. Analisis data yang digunakan adalah statistik nonparametrik Mann-Whitney untuk uji beda resiliensi akademik berdasarkan jenis kelamin dan Kruskal Wallis sebagai uji beda pada tingkatan kelas (angkatan). Hasil studi menunjukkan bahwa berdasarkan lima prediktor resiliensi akademik, diketahui tidak terdapat perbedaan antara mahasiswa perempuan dan mahasiswa laki-laki. Hasil penelitian juga menunjukkan bahwa secara signifikan terdapat perbedaan resiliensi akademik antara mahasiswa angkatan 2013, 2014 dan 2015. Diskusi, keterbatasan dan rekomendasi dibahas dalam studi ini.
\end{abstract}

Kata kunci: resiliensi; tahun akademik; perempuan; laki-laki; mahasiswa 


\section{INTRODUCTION}

Resilience is a description of the success of the process and the results of adaptation to difficult circumstances or very challenging life experiences, especially situations with high-stress levels (Howard \& Johnson, 2000). Simply put, resilience can be interpreted as the ability to bounce back from adversity, frustration, and adversity (Ledesma, 2014). It is broadly used to describe how complex and intricate a person's response toward difficult, traumatic, and challenging situations (Aburn, Gott, \& Hoare, 2016).

Basically, resilience is a positive pattern of adaptation in difficult situations (Masten \& Gewirtz, 2006; Masten et al., 2010). Resilience is the ability to cope with life changes at a high level, maintain health in stressful conditions, rise from adversity, overcome adversity, adjust the way of life according to existing conditions, and face problems without committing acts of violence (Siebert, 2005). In a broader perspective, resilience is seen as an ability that develops throughout life and describes a person's intellectual ability to utilize various resources to face various challenges (Pooley \& Cohen, 2010).

From various descriptions of resilience, it can be interpreted that resilience is a person's ability to continue to withstand the various obstacles experienced and adapt to these conditions to achieve optimal success. Resilience has a broad and varied meaning, especially in the science of human development. Resilience includes the scope of a person's ability to recover from traumatic times, overcome failures in life, or the ability to manage stresses in various contexts that occur throughout life's vulnerability, which provides energy to a person so that they are able to survive and carry out daily life effectively.

Resilience in an academic context is known as academic resilience. Academic resilience is a term that refers to a student's capacity to overcome difficulties that are considered severe or chronic in the educational process being undertaken (Martin \& Marsh, 2009). According to Martin (2002), Academic resilience is a term based on a person's ability to achieve better academic achievement than expected after facing a negative event or difficult situation. Academic resilience is the process and success of individuals to achieve academically despite the obstacles, where most others with the same background fail (Morales, 2008).

Students often face various difficult academic and social conditions at school, on campus, at home, and in society. Poverty can be one of the factors that hinders students' development and psychological adjustment so that students with economically weak categories become the cluster most likely to experience academic failure due to tough socio-economic situations (Kanevsky et al., 2008). However, a study revealed that economically disadvantaged students who can overcome difficult situations and face challenges successfully could become individuals who can adjust well and lead productive lives (Gizir $\&$ Aydin, 2009). Therefore, it is important for policymakers and education practitioners to pay attention to the quality of student resilience.

Scales et al. (2006) found that resilience has a high correlation with students' achievement index in America at various schools at the high school level. Various studies have also shown that the various resilience skills developed by students can have a significant effect on academic performance (Christine, 2010). Several studies related to academic resilience focus on specific ethnic groups or groups of students (Gizir \& Aydin, 2009; Borman \& Overman, 2004). However, research on academic resilience is relevant to all students, including students at the university. All students at all academic levels tend to experience various difficulties, challenges, pressures, or poor performance in the academic process (Martin \& Marsh, 2006). Resilience should be a concern for universities considering this can be a factor in student survival in studying at higher education.

Statistical data from the Ministry and Directorate of Higher Education recorded that the number of students dropping out of college in 2017 was 195,176 (2.8\%) of the total 6.92 million students who were registered as active. This figure even shows an increasing trend in 2018, reaching 239,498 (3\%) of the 6.95 million active students (Kemenristekdikti, 2017; Kemenristekdikti, 2018). Academic resilience is one of the factors that can make a person experience failure in the learning process and even lead to dropping out of the school process (Frisby et al., 2020).

The purpose of this study was to determine the characteristics of students' resilience based on gender and cohort. Understanding the characteristics of student resilience can be an input for related units at the university, in this case the counseling unit or the like, to pay attention to the quality of student resilience at the university and to carry out appropriate counseling programs for students who have poor resilience scores. Studies related to resilience are also input and consideration for faculties and study 
programs in developing appropriate academic and student programs to improve the quality of students' resilience. Researchers who focus on resilience believe that resilience can be developed with the right treatment or certain factors (Reivich \& Shatté, 2002).

\section{METHOD}

This study employed a cross-sectional survey. It aims at exploring the dynamics of the correlation between causal factors and effects. To gather data, ARS instrument was used. It has been adapted and modified from the ARS proposed by Martin and Marsh (2006) by classifying the survey results based on gender and student cohort.

Participants in this study were 103 students ( 77 female and 26 male) who were majoring in Educational Psychology and Guidance at Universitas Negeri Malang, Indonesia, recruited using a probability-stratified sampling technique. They consisted of 42 students from classes of 2013, 34 from class of 2014, and 27 students from class of 2015. The participants were recruited since they are late adolescents aged 18-23 years and will enter a transition period to adulthood. The challenges faced were increasingly complex and varied, so it requires toughness in dealing with them.

According to Martin and Marsh (2006), Academic resilience is built on five predictors known as the 5-C model, namely confidence, coordination, control, composure, and commitment. Based on these predictors, they developed ARS consisting of six statement items accompanied by choice of answers on a scale of 1-7. ARS has been tested on 402 students and shows high validity and reliability. Thus, it is appropriate to be used to measure the level of student academic resilience.

ARS has six statement items with answer choices on a scale of 1-7 (Not true of me at all to Extremely true of me) from five predictors that constitute resilience. The predictors are self-efficacy, planning, control, low anxiety, and persistence. However, in this study, the 6 items were developed into 15 statement items with a choice of answers on a scale of $1-8(1=$ very inappropriate, $8=$ very suitable $)$ and had three statement items for each predictor. Before the instrument was tested for validity and reliability, a material test was first conducted by two experts in the field of guidance and counseling to test the suitability of the theoretical construct and instrument items. After going through the expert judgment process, the instruments were distributed to the student group and tested for validity and reliability. The SPSS statistical test showed that the validity of the instrument is at a significance level of $0.01(1 \%)$ while the reliability shows a score of 0.893 . Therefore, this study used an ARS that has been adapted in measuring the level of student academic resilience based on differences in gender and cohort.

Data analysis in this study used statistical non-parametric Mann-Whitney $U$ test. To see differences in academic resilience between men and women as well as differences between men and women in five predictors of academic resilience based on the cohort, data analysis was used using Kruskal Wallis. To see the average difference between men and women as well as the average difference between men and women in each aspect based on the cohort used non-parametric test 2 Independent Samples and K Independent Samples.

\section{RESULTS}

This section presents the results in two parts. The first part contains an overview of academic resilience based on gender, namely the differences between men and women in five predictors of academic resilience, such as self-efficacy, planning, control, low anxiety, and persistence. It is presented in Table 1. The second part contains an overview of academic resilience based on the cohort of the five predictors of academic resilience. It is presented in Table 2.

From Table 1, it can be seen that there is a difference in the average score of academic resilience between women and men. The mean score for males shows a higher number than females in all aspects. The results of different tests using Mann-Whitney on the aspects of self-efficacy, persistence, low anxiety, and control show that there are no significant differences between women and men. This is because the significance value shown in each aspect is above 0.05 . The difference between men and women in the planning aspect is at a significance level below 0.05 . This means that of the five predictor aspects of academic resilience, only the planning aspects of women and men differ significantly. 
Table 1. Academic Resilience Based on Gender

\begin{tabular}{lccccc}
\hline Variable & Gender & N & Mean & Sum & Sig. (Mann-Whitney) \\
\hline Self-efficacy & Women & 77 & 49.71 & 3828.00 & 0.180 \\
& Man & 26 & 58.77 & 1528.00 & \\
& Total & 103 & & & 0.398 \\
Persistence & Women & 77 & 50.56 & 3893.00 & \\
& Man & 26 & 56.27 & 1463.00 & \\
& Total & 103 & & & 0.118 \\
Low anxiety & Women & 77 & 49.34 & 3799.00 & \\
& Man & 26 & 59.88 & 1557.00 & 0.054 \\
Control & Total & 103 & & & \\
& Women & 77 & 48.72 & 3751.50 & 0.022 \\
& Man & 26 & 61.71 & 1604.50 & \\
& Total & 103 & & & \\
& Women & 77 & 48.10 & 3703.50 & \\
& Man & 26 & 63.56 & 1652.50 & \\
\hline
\end{tabular}

Table 2. The Difference in the Mean Score of Academic Resilience Based on Cohort

\begin{tabular}{|c|c|c|c|c|}
\hline Variable & Cohort & $\mathbf{N}$ & Mean & Sig. ( Kruskal Wallis) \\
\hline \multirow[t]{4}{*}{ Self-efficacy } & 2013 & 42 & 64.82 & 0.000 \\
\hline & 2014 & 34 & 36.93 & \\
\hline & 2015 & 27 & 51.04 & \\
\hline & Total & 103 & & \\
\hline \multirow[t]{4}{*}{ Persistence } & 2013 & 42 & 67.68 & 0.000 \\
\hline & 2014 & 34 & 29.76 & \\
\hline & 2015 & 27 & 55.61 & \\
\hline & Total & 103 & & \\
\hline \multirow[t]{4}{*}{ Low anxiety } & 2013 & 42 & 65.05 & 0.000 \\
\hline & 2014 & 34 & 37.49 & \\
\hline & 2015 & 27 & 49.98 & \\
\hline & Total & 103 & & \\
\hline \multirow[t]{4}{*}{ Control } & 2013 & 42 & 63.60 & 0.002 \\
\hline & 2014 & 34 & 40.18 & \\
\hline & 2015 & 27 & 48.85 & \\
\hline & Total & 103 & & \\
\hline \multirow[t]{4}{*}{ Planning } & 2013 & 42 & 53.63 & 0.810 \\
\hline & 2014 & 34 & 49.32 & \\
\hline & 2015 & 27 & 52.83 & \\
\hline & Total & 103 & & \\
\hline
\end{tabular}

From Table 2, it can be seen that there are differences in academic resilience among students based on cohort. Based on the mean score of academic resilience, it can be seen that students of class 2014 have the highest mean score, followed by class 2015 and class 2014 .

In the Kruskal Wallis different test, it is observed that in the aspects of self-efficacy, persistence, low anxiety, and control, there are significant differences in academic resilience between students of 2013, 2014, and 2015, with a significance level below 0.05. Meanwhile, in the planning aspect, there is no significant difference between students of 2013, 2014, and 2015, with a significance level above 0.05 . 


\section{DISCUSSION}

This study is intended to determine the level of academic resilience based on differences in gender and cohort. The choice of research cluster based on gender is intriguing to explore as, physiologically and psychologically, men and women have different tendencies from each other (Morales, 2008). In addition, research based on differences in the cohort is intended to see whether differences in batch years have a significant effect on students' level of resilience.

The results showed that basically, there was a difference in the mean score between men and women, where the mean score of men showed a higher number than women. However, the MannWhitney independent sample test shows that there are four aspects of resilience that show no significant difference between men and women, namely in the aspects of self-efficacy, persistence, low anxiety, and control. A significant difference is only shown in the planning aspect, which means that in an academic context, male students have a better planning tendency than female students.

The results of this study are in line with the previous research by Kapikiran (2012) who conducted research in Turkey and unraveled that academic resilience has no correlation with gender. Kim and Yoo (2010) also found that there was no difference in academic resilience in children with cancer in Seoul, Korea, based on gender. The results of this study are also consistent with research conducted by Martin and Marsh (2006) in Australia, which showed that boys and girls do not differ substantially in academic resilience.

On the other hand, this study contradicts a study by Khalaf (2014). The study shows that men and women have significant differences in the level of academic resilience. Research conducted by Sarwar et. al. (2010) in Pakistan also identified that men are more resilient than women. Research conducted by Morales (2008) also shows that there are significant differences between men and women in academic resilience where women are more resilient than men. Somchit and Sriyaporn (2004) also stated that women have higher resilience than men.

There are differences in the results of research conducted by previous researchers because resilience is formed from a variety of varied factors, not only related to gender differences but also related to the context of events, time, age, and cultural influences (Andriani \& Listiyandini, 2017). Resilience is also influenced by differences in education levels, levels of traumatic experiences, social support obtained, and past and present life pressures (Bonanno et al., 2007). These differences also contribute to the differences in results obtained by various studies on resilience based on sex differences.

Resilience, initially seen as an ability that comes only from personal factors and intellectual functions that make a person able to survive in various difficult situations. As the understanding of resilience develops, it is revealed that resilience is an ability that develops due to the influence of various negative events in life, such as experiences of poor parenting, poverty, traumatic events, natural disasters, violence, war, and physical illness (Herrman et. al., 2011).

Resilience is formed from a series of processes faced by a person (Morales, 2008). Elizabeth and Mark (2018) and Luthar et al. (2000) views resilience as a dynamic process over time and depending on the context. Several studies have shown that differences in resilience between men and women are also influenced by biological factors (Rinaldi, 2010), socio-demographic factors (Wardhani et al., 2017), and socio-emotional factors (Sunarti et al., 2018). Generally, women tend to use emotion-focused coping more often in dealing with pressure when having problems, namely by placing more emphasis on overcoming emotional impacts that arise (Brougham et al., 2009). Physical differences also have an impact on the resilience of men and women. Women are considered more difficult to manage and access resources that can help them solve the problems they face, so they are more easily swayed than men (Kumar \& Quisumbing, 2014). If analyzed more simply, it can be concluded that resilience is formed and influenced by at least three things, namely: personality factors, biological factors, and environmental factors (Herrman et. al., 2011).

This study also reveals that there are differences in the level of resilience among students based on the cohort. This study informs that students in the class of 2013 have better academic resilience than students in the classes of 2014 and 2015. This can be due to differences in experience and maturity in facing the intensity and process of lectures. Students in the class of 2013 have more mature experience in taking the education process at university, so they tend to be more resilient to pressures and demands, in contrast to the 2014 and 2015 classes which are still new and need time to adapt. This echoes Grotberg 
(2004), who contends that the level of age can influence the quality of a person's resilience, level of development, the intensity of a person in dealing with unpleasant situations, as well as how much social support is in shaping a person's resilience.

The results of this study differ from the previous research conducted by Khalaf (2014) who found that there was no significant difference in the level of academic resilience based on differences in the age of the student cohort. On the one hand, it corresponds to the research done by Somchit and Sriyaporn (2004), which shows that age does not have a significant effect on the level of student academic resilience.

The new atmosphere felt by students in the first year has a significant effect on students' resilience abilities. In general, first-year students are vulnerable to low category resilience scores (Prihartono et al., 2018) or moderate (Fitri \& Kushendar, 2019). Because when in college, they are required to be more independent in managing their own time, making more mature decisions, and being responsible because they are in a different academic and social situation than before (Andriani \& Listiyandini, 2017).

This study identifies that the 2015 class has a higher level of academic resilience compared to the 2014 class. This is interesting because the 2015 class as junior high school students are in a transition period from high school to university, so they are prone to experiencing difficult academic situations due to the adaptation process. The factor that can affect the level of student resilience in 2015 so that it is better than students of the 2014 class is the ability to adapt positively to the situation and academic stresses they are experiencing (Hendriani, 2017). Moreover, new students, in general, have intrinsic motivation to prove that they deserve to be in the university. This desire eventually leads to self-esteem in the students of class 2015. According to Hanani (2019), There is an influence between self-esteem on resilience in first-year students. In general, studies that show a link between self-esteem and resilience are quite common (Earvolino-Ramirez, 2007).

New students who are dominated by migrants also require them to have good social intelligence to survive in an environment far from their parents. Social intelligence, in general, has a significant role in the resilience of first-year students, which is $16 \%$, while the remaining $84 \%$ is influenced by other factors (Andriani \& Listiyandini, 2017). Their status as new students also requires students to provide mutual support to one another. The support obtained by fellow classmates has a positive influence on student resilience abilities (Frisby et al., 2020).

Researchers who focus on resilience believe that resilience is an ability that can be developed with the right treatment or certain factors (Reivich \& Shatté, 2002). Therefore, the findings of this study serve as recommendations to technical guidance and counseling units or similar units and institutions in providing counseling services for students. In addition, this study can also be used as material for thought in preparing and implementing the right program to improve the quality of student resilience. The findings also contribute thoughts and input to the faculty and departments in order to evaluate and develop appropriate and relevant academic and student programs to increase student resilience in the Department of Educational Psychology and Guidance.

Although the findings of this study shed light on the importance of academic resilience, the study is open to some limitations. First, the participants involved in this study were still on a small scale, making it difficult to generalize the findings more broadly. Second, this study is limited to tracing differences in sex and cohort, so it is necessary to add other demographic elements such as parental occupation, parental education, ethnicity, religion, neighborhood, and so on. Lastly, this study did not explore qualitatively why men and women have differences in aspects of academic resilience.

\section{CONCLUSION}

This study has indicated that gender has no effect on the level of students' academic resilience. Both genders have the same opportunity to increase academic resilience by developing aspects of selfefficacy, persistence, low anxiety, control, and planning. The results of this study also confirm that there are differences in the level of academic resilience based on students' cohort. Future research is encouraged to explore a larger population and more diverse demographic aspects. This needs to be done so that a wider generalization can be done. Future research can also use qualitative method to dig deeper into levels of academic resilience based on gender and age. Besides, testing the academic resilience scale instrument at the elementary, junior, and high school levels are recommended so that the use of this scale is not only intended for students. 


\section{REFERENCES}

Aburn, G., Gott, M., \& Hoare, K. (2016). What is resilience? An integrative review of the empirical literature. Journal of Advanced Nursing, 72(5), 980-1000.

Andriani, A., \& Listiyandini, R. A. (2017). Peran kecerdasan sosial terhadap resiliensi pada mahasiswa tingkat awal. Psympathic: Jurnal Ilmiah Psikologi, 4(1), 67-90. https://doi.org/10.15575/psy.v4i1.1261

Bonanno, G. A., Galea, S., Bucciarelli, A., \& Vlahov, D. (2007). What predicts psychological resilience after disaster? The role of demographics, resources, and life stress. Journal of Consulting and Clinical Psychology, 75(5), 671-682. https://doi.org/10.1037/0022-006X.75.5.671

Borman, G. D., \& Overman, L. T. (2004). Academic resilience in mathematics among poor and minority students. Elementary School Journal, 104(3), 177-195. https://doi.org/10.1086/499748

Brougham, R. R., Zail, C. M., Mendoza, C. M., \& Miller, J. R. (2009). Stress, sex differences, and coping strategies among college students. Current Psychology, 28(2), 85-97. https://doi.org/10.1007/s12144-009-9047-0

Christine, D. B. (2010). A review of the literature resiliency skills and dropout prevention. ScholarCentric.com.

Earvolino-Ramirez, M. (2007). Resilience: A concept analysis. In Nursing forum (Vol. 42, pp. 73-82). Wiley Online Library.

Fitri, H. U., \& Kushendar, K. (2019). Konseling kelompok cognitive restructuring untuk meningkatkan resiliensi akademik mahasiswa. Bulletin of Counseling and Psychotherapy, 1(2)(2), 67-74.

Frisby, B. N., Hosek, A. M., \& Beck, A. C. (2020). The role of classroom relationships as sources of academic resilience and hope. Communication Quarterly, 68(3), 289-305.

Gizir, C. A., \& Aydin, G. (2009). Protective factors contributing to the academic resilience of students living in poverty in Turkey. Professional School Counseling, 13(1), 2156759X0901300. https://doi. org/10.1177/2156759x0901300103

Grotberg, E. H. (2004). Children and caregivers: The role of resilience. In International Council of Psychologists (ICP) Convention Jinan, China.

Hanani, C. A. (2019). Pengaruh self-esteem terhadap resiliensi pada mahasiswa tahun pertama program studi kedokteran. Universitas Negeri Jakarta.

Hendriani, W. (2017). Adaptasi positif pada resiliensi akademik mahasiswa doktoral. Humanitas, 14(2), 139-149. https://doi.org/10.26555/humanitas.v14i1.5696

Herrman, H., Stewart, D. E., Diaz-Granados, N., Berger, E. L., Jackson, B., \& Yuen, T. (2011). What is resilience? The Canadian Journal of Psychiatry, 56(5), 258-265.

Howard, S., \& Johnson, B. (2000). What Makes the Difference? Children and teachers talk about resilient outcomes for children "at risk." Educational Studies, 26(3), 321-337. https://doi.org/10.1080/03055690050137132

Kanevsky, L., Corke, M., \& Frangkiser, L. (2008). Characteristics of inner- city English learners school program. Education and Urban Society, 20(10), 452-475.

Kapikiran, S. (2012). Validity and reliability of the academic resilience scale in Turkish high school. Education, $132(3), 474-484$.

Kemenristekdikti. (2017). Statistik Pendidikan Tinggi Tahun 2017. Jakarta: Pusdatin Iptek Dikti.

Kemenristekdikti. (2018). Indonesia Higher Education Statistical Year Book 2018.

Khalaf, M. A. (2014). Validity and reliability of the academic resilience scale in Egyptian context. US-China Education Review, 4(3), 202-210.

Kim, D. H., \& Yoo, I. Y. (2010). Factors associated with resilience of school age children with cancer. Journal of Paediatrics and Child Health, 46(7-8), 431-436. https://doi.org/10.1111/j.1440-1754.2010.01749.x

Kumar, N., \& Quisumbing, A. (2014). Gender and resilience. In S. Fan, R. Pandya-Lorch, \& S. Yosef (Eds.), Resilience for food and nutrition security: An IFPRI 2020 book (pp. 155-167). Washington, DC: IFPRI.

Ledesma, J. (2014). Conceptual frameworks and research models on resilience in leadership. Sage Open, 4(3), 2158244014545464. https://doi.org/10.1177/2158244014545464

Luthar, S. S., Cicchetti, D., \& Becker, B. (2000). The construct of resilience: A critical evaluation and guidelines for future work. Child development, 71(3), 543-562.

Martin, A. (2002). Motivation and academic resilience: Developing a model for student enhancement. Australian Journal of Education, 46(1), 34-49. https://doi.org/10.1177/000494410204600104

Martin, A. J., \& Marsh, H. W. (2006). Academic resilience and its psychological and educational correlates: A construct validity approach. Psychology in the Schools, 43(3), 267-281 
Martin, A. J., \& Marsh, H. W. (2009). Academic resilience and academic buoyancy: Multidimensional and hierarchical conceptual framing of causes, correlates and cognate constructs. Oxford Review of Education, 35(3), 353-370. https://doi.org/10.1080/03054980902934639

Masten, A., \& Gewirtz, A. (2006). Resilience in development: The importance of early childhood. Encyclopedia on Early Childhood Development, (January 2006), 1-6.

Masten, A. S., Gewirtz, A. H., \& Sapienza, J. K. (2010). Resiliencia en el desarrollo: la importancia de la primera infancia. Enciclopedia Sobre El Desarrollo de La Primera Infancia, 1-6.

Morales, E. E. (2008). Exceptional female students of color: Academic resilience and gender in higher education. Innovative Higher Education, 33(3), 197-213. https://doi.org/10.1007/s10755-008-9075-y

Pooley, J. A., \& Cohen, L. (2010). Resilience: A definition in context. Australian Community Psychologist, 22(1), $30-37$.

Prihartono, M. N., Sutini, T., \& Widianti, E. (2018). Gambaran resiliensi mahasiswa tahun pertama program A2016 Fakultas Keperawatan Universitas Padjajaran. Jurnal Keperawatan BSI, 6(1), 96-104.

Reivich, K., \& Shatté, A. (2002). The resilience factor: 7 essential skills for overcoming life 's inevitable obstacles. Broadway books.

Rinaldi, R. (2010). Resiliensi pada masyarakat Kota Padang ditinjau dari jenis kelamin. Jurnal Ilmiah Psikologi Gunadarma, 3(2), 99-105.

Sarwar, M., Inamullah, H., Khan, N., \& Anwar, N. (2010). Resilience and academic achievement of male and female secondary level students in Pakistan. Journal of College Teaching \& Learning (TLC), 7(8), 19-24. https://doi.org/10.19030/tlc.v7i8.140

Scales, P. C., Benson, P. L., Roehlkepartain, E. C., Sesma, A., \& van Dulmen, M. (2006). The role of developmental assets in predicting academic achievement: A longitudinal study. Journal of Adolescence, 29(5), 691-708. https://doi.org/10.1016/j.adolescence.2005.09.001

Siebert, A. (2005). The resiliency advantage: Master change, thrive under pressure, and bounce back from setbacks. Berrett-Koehler Publishers.

Somchit, S., \& Sriyaporn, P. (2004). The relationships among resilience factors, perception of adversities, negative behavior, and academic achievement of 4th-to 6th-grade children in Thad-Thong, Chonburi, Thailand. Journal of Pediatric Nursing, 19(4), 294-303. https://doi.org/10.1016/j.pedn.2004.02.004

Sunarti, E., Islamia, I., Rochimah, N., \& Ulfa, M. (2018). Resiliensi remaja: Perbedaan berdasarkan wilayah, kemiskinan, jenis kelamin, dan jenis sekolah. Jurnal Ilmu Keluarga dan Konsumen, 11(2), 157-168. https:// doi.org/10.24156/jikk.2018.11.2.157

Tudor, K. E., \& Spray, C. M. (2017). Approaches to measuring academic resilience: A systematic review. International Journal of Research Studies in Education, 7(4), 41-61.

Wardhani, R. H., Sunarti, E., \& Muflikhati, I. (2017). Ancaman, faktor protektif, aktivitas, dan resiliensi remaja: Analisis berdasarkan tipologi sosiodemografi. Jurnal Ilmu Keluarga dan Konsumen, 10(1), 47-58. https:// doi.org/10.24156/jikk.2017.10.1.47 